\title{
Formation of the thermohaline structure of water in the Bahía de La Paz from summer to autumn
}

\section{Formación de la estructura termohalina del agua en la Bahía de La Paz de verano a otoño}

\author{
Felipe Salinas-González \\ Oleg Zaytsev* \\ Vyacheslav Makarov \\ Oceanology Departament, CICIMAR-IPN \\ Av. Instituto Politécnico Nacional, $\mathrm{s} / \mathrm{n}$ \\ Col. Playa Palo de Santa Rita \\ La Paz, Baja California Sur, CP 23096, México \\ *E-mail: ozaytsev@ipn.mx
}

Recibido en enero de 2002; aceptado en diciembre de 2002

\begin{abstract}
The summer-autumn formation of the thermohaline structure of the coastal deepwater body was studied in Bahía de La Paz, Gulf of California, from measurements the thermohaline variables taken in October 1997, November 1998, August 1999, and in an adjacent area of the Gulf of California in July 1997. In August 1999, intense density stratification was recorded from the surface to 60-m depth, because of a positive daily heat balance and weak vertical mixing. In autumn (Oct. 1997 and Nov. 1998), the upper mixed layer (ML) was 40-50-m thick, and the thermocline had a maximum vertical gradient up to $0.6^{\circ} \mathrm{C}$ per meter. The three-dimensional distribution of density shows concave isopycnics towards the center of the bay, suggesting the possible existence of anticyclonic vorticity. The non-uniformity of this spatial mass field was formed by local heating and evaporation processes, and by the water exchange with the open ocean through the mouths of the bay. The physical reasons for the variations in the ML are discussed. The deepwater body $(>150 \mathrm{~m})$ maintained almost constant thermohaline variables during the study and no noticeable variations were detected in the surface layer. The T-S diagrams were different from those of the Gulf of California water mass and similar to Subtropical Subsurface waters ones (less saline). In October 1997 , a $2.5^{\circ} \mathrm{C}$ increase in temperature was measured at the surface layer which considered related to the peak of the 1997 El Niño.
\end{abstract}

Key words: Gulf of California, density distribution, mixed layer, seasonal transformation, T-S diagrams.

\section{Resumen}

Se estudió la formación de la estructura termohalina en el cuerpo costero profundo de la Bahía de La Paz, Golfo de California en la época de verano-otoño, a partir de mediciones de parámetros termohalinos recolectados en los meses de octubre de 1997, noviembre de 1998, agosto de 1999 y en la zona adyacente del Golfo de California en julio de 1997. En agosto de 1999 se registró una estratificación intensa de densidad desde la superficie hasta los $60 \mathrm{~m}$ de profundidad, debido al balance positivo diario de calor y a la débil mezcla vertical. En otoño (octubre de 1997 y noviembre de 1998), la capa superficial de mezcla (ML) fue de 40$50 \mathrm{~m}$ de espesor y la termoclina tuvo un gradiente vertical máximo de hasta $0.6^{\circ} \mathrm{C}$ por metro. La distribución tridimensional de densidad muestra la concavidad de las isopicnas al centro de la bahía, sugiriendo la posible existencia de vorticidad anticiclónica. La no uniformidad espacial de este campo de masa se formó por los procesos locales de calentamiento, evaporación, y por el intercambio de agua con el mar abierto a través de las bocas de la bahía. Se discutieron las razones físicas de las variaciones en la ML. El cuerpo de agua profundo ( $>150 \mathrm{~m}$ ) mantuvo sus parámetros termohalinos casi constantes durante la experimentación y no se detectaron variaciones apreciables en la capa superficial. Los diagramas T-S fueron distintos a los del Agua del Golfo de California, y similares a los de las Aguas Subsuperficiales Subtropicales (menos salinas). En octubre de 1997 se registró un incremento de temperatura de $2.5^{\circ} \mathrm{C}$, el cual se consideró, estuvo relacionado con el máximo de El Niño de 1997.

Palabras claves: Golfo de California, distribución de densidad, capa de mezcla, transformación estacional, diagramas T-S.

\section{Introduction}

The Baja California Peninsula has a long coastline with many bays and lagoons along its coasts. One of the most important ones is Bahía de La Paz in the southwestern Gulf of California, close to the city of La Paz, the sate capital of Baja

\section{Introducción}

La Península de Baja California tiene una larga línea de costa con muchas bahías y lagunas. Una de las más importantes es la Bahía de La Paz al suroeste del Golfo de California, próxima a la capital del estado de Baja California Sur (BCS). 
California Sur (BCS). The area is economically attractive because of its fishing and tourism industry supported by the high biological productivity and the many recreational areas. The ecological and morphological changes in the bay are related to the hydrophysical conditions of the waterbody including the thermohaline structure, currents and transport of suspended and dissolved matter. Due to its geographic position Bahía de La Paz is relatively isolated from most of the hydrophysical processes that occur in the Gulf of California.

Although the bay is located close to the city of La Paz, its waterbody has not been well studied because the studies made to date have been sporadic and are incomplete. There are few works published on the hydrology and hydrodynamics of the bay. Some interesting questions are: is the waterbody of the bay part of the Gulf of California water mass? or, are its hydrological properties created by local heating and evaporation processes? and how is the three-dimensional thermohaline structure transformed during the warming season form summer to autumn?

Previous studies of the adjacent area of the Gulf of California located close to Bahía de La Paz and of the mouth of the Gulf of California (Roden, 1972; Álvarez-Sánchez et al., 1978; Álvarez-Borrego and Schwartzlose, 1979; BadanDangon et al., 1985; Blanco-Betancourt, 1996; Lavín and Badan-Dangon, 1997) show that the southern part of the gulf has very complex hydrodynamics. At least three water masses converge, and there are upwelling zones, dynamic fronts and vorticity structures. The current field is complex and variable and may have the potential to force the exchange of water with Bahía de La Paz through the main mouth, which has depths up to $350 \mathrm{~m}$. Obeso et al. (1993) made some preliminary studies on the tidal current patterns in the bay by the hydrodynamic modeling of the shallow waters (modified by Dressler, 1982) using only few experimental data. The results of the simulation showed that tidal currents occur in the range of 3 to $8 \mathrm{~cm} / \mathrm{s} \mathrm{dur-}$ ing the ebb and flow, and that the intensity of these currents cannot significantly change the thermohaline structure. The currents in the San Lorenzo Channel (with depths up to $18 \mathrm{~m}$ ) were of considerable magnitude $(20-25 \mathrm{~cm} / \mathrm{s})$.

Some information on the temperature and salinity was published in the works of Villaseñor (1978) and Jiménez et al. (1994), but these data are insufficient to reconstruct the thermohaline structure in the bay. Furthermore, there is limited information on these dynamic processes and their temporal variability. Salinas-González et al. (1997) analyzed the time series of tides and bottom currents, and showed the existence of residual currents at the head of the bay. Some preliminary results of this study have been published by Zaytsev et al. (1998).

High solar radiation and intense evaporation cause the seasonal stratification in summer. The surface mixed layer (ML) is formed in September, due to the intensification of the wind (up to $11 \mathrm{~m} / \mathrm{s}$ ); below it, there is a strong decreasing temperature gradient that disappears in winter. The depth of the bay allows the stratification of the water column, and its spatial
La zona es económicamente atractiva por su potencial pesquero e industria turística, sustentados en la alta productividad biológica y sus áreas de recreo. Los cambios ecológicos y morfológicos en la bahía están relacionados con el estado hidrofísico de su cuerpo de agua incluyendo la estructura termohalina, las corrientes y el transporte de material suspendido y disuelto. Debido a la situación geográfica de la Bahía de La Paz, ésta se encuentra relativamente aislada de la mayor parte de los procesos hidrofísicos que se dan en el Golfo de California.

A pesar de que la bahía se localiza cerca de la ciudad de $\mathrm{La}$ Paz, su cuerpo de agua no ha sido bien estudiado hasta el momento ya que las investigaciones realizadas han sido esporádicas e incompletas, siendo escasos los trabajos publicados sobre hidrología e hidrodinámica de la misma. Entre las interrogantes de interés están: ¿Es el cuerpo de agua de la bahía parte de las masas de agua del Golfo de California? o ¿son sus aguas formadas por procesos locales de calentamiento y evaporación?, y ¿cómo se transforma la estructura termohalina tridimensional durante la época de calentamiento de verano-otoño?

Estudios previos del Golfo de California en la región adyacente de la Bahía de La Paz y en la boca del Golfo de California (Roden, 1972, Álvarez-Sánchez et al., 1978, Álvarez-Borrego y Schwartzlose, 1979, Badan-Dangon et al., 1985, Blanco-Betancourt, 1996; Lavín y Badan-Dangon, 1997), muestran que la parte sur del golfo es muy dinámica ya que por lo menos convergen en ella tres masas de agua, existiendo zonas de surgencias, frentes dinámicos y estructuras de vorticidad. El campo de corrientes es complejo, variable y potencialmente puede forzar el intercambio del agua con la Bahía de La Paz a través de la boca principal que tiene profundidades de hasta $350 \mathrm{~m}$.

Algunas investigaciones preliminares del patrón de corrientes de marea en la bahía fueron realizadas por Obeso et al. (1993) mediante un modelo hidrodinámico de aguas someras (modificado por Dressler, 1982), usando pocos datos experimentales. Los resultados de la simulación mostraron que durante el flujo y reflujo las corrientes de marea se encuentran en el rango de $3-8 \mathrm{~cm} / \mathrm{s}$, y la intensidad de estas corrientes no puede cambiar significativamente la estructura termohalina. Las corrientes en el Canal de San Lorenzo (con profundidad hasta de $18 \mathrm{~m}$ ) fueron de magnitud considerable $(20-25 \mathrm{~cm} / \mathrm{s})$.

La escasa información que existía sobre temperatura y salinidad fue publicada en los trabajos de Villaseñor (1978) y Jiménez et al. (1994), pero dichos datos son insuficientes para reconstruir la estructura termohalina en la bahía. También, existe información limitada sobre los procesos dinámicos y su variabilidad temporal; Salinas-González et al. (1997) analizaron las series de tiempo de corrientes y mareas de fondo mostrando la existencia de corrientes residuales al Oeste de la cabecera de la bahía. Algunos resultados preliminares del presente estudio se han publicado en Zaytsev et al. (1998).

La intensa radiación solar e intensa evaporación causan la estratificación en verano. La capa superficial de mezcla (ML) es formada en septiembre debido a la intensificación de los 
nonuniformity causes a baroclynic state. The spatial variations (horizontal and vertical) of the density field can impose a thermohaline circulation. This type of water movement is not intense but it remains along the seasonal period and determines the long-time mass transport in the bay (Atkinson, 1986). The thermohaline circulation in the coastal bodies, together with the tidal and wind-derived currents can produce different dynamic elements such as gyres, upwelling and convergence, which play an important role in the evolution of the coastal ecosystems and contaminant dispersion.

\section{Study area}

Bahía de La Paz is the largest bay on the East coast of the Baja California Peninsula. It is about $80-\mathrm{km}$ long and up to 35$\mathrm{km}$ wide. Its bottom topography is variable (Cruz-Orozco et $a l ., 1996$ ). The southern part is relatively shallow (up to $40 \mathrm{~m}$ ). The northern part is deep, with an Alfonso depression (up to 450-m depth) and a well-defined channel at the main mouth between $220-$ and $320-\mathrm{m}$ deep. The water exchange between the bay and the gulf is mainly through the main mouth and partially through the San Lorenzo Channel (up to 18-m depth) in the eastern part of the bay.

The climate of the region of $\mathrm{La} \mathrm{Paz}$ is dry, semi desert, with a mean annual temperature between $22^{\circ} \mathrm{C}$ and $24^{\circ} \mathrm{C}$. It has a rainy season in summer, with a mean annual rainfall less than $200 \mathrm{~mm}$ (Roden, 1958). In summer there is a prevailing system of breezes that cause daily changes in the wind. Dominant winds from the South occur from March to August, whereas winds from the Northwest occur from October to February. The chain of mountains along the Baja California Peninsula is an obstacle for the NW winds and breezes from the Pacific Ocean to freely penetrate in the bay. There is also the influence of tropical storms from the South in the summer and cyclones from the North in the winter. The study area, bathymetry, and the sampling grid are shown in figure 1.

\section{Methods}

Measurements of the hydrological variables in a grid of 54 stations in Bahía de La Paz were obtained during field trips from October 22-25, 1997, and from August 18-20, 1999 (fig. $1)$. This grid was also partially measured from November 18 20, 1998. The grid of stations was organized in nine lines with six stations each. The profiles of temperature, conductivity, and pressure were obtained with a SeaBird SB-25 CTD (with resolutions in temperature of $0.001^{\circ} \mathrm{C}$, conductivity of $0.00005 \mathrm{~S} / \mathrm{m}$ and depth of $0.00005 \%$ in the $350-\mathrm{m}$ range), the calibrations were made according to the manual of the instrument, the sampling depth was from 70 to $350 \mathrm{~m}$. The data were recorded at 8 $\mathrm{Hz}$ frequency and averaged to each meter of depth. To recognize the fine vertical variability in each of the layers averaged, the standard deviation of the variables measured was determined. The horizontal distributions of temperature $\left({ }^{\circ} \mathrm{C}\right)$, vientos (hasta de $11 \mathrm{~m} / \mathrm{s}$ ) y por debajo de ella existe un fuerte gradiente de temperatura que desaparece a finales del invierno. La profundidad de la bahía permite la estratificación de su columna de agua y su no-uniformidad espacial da origen a un estado baroclínico. Las variaciones espaciales (horizontales y verticales) del campo de densidad pueden imponer una circulación termohalina. Este tipo de movimiento del agua no es intenso, pero se mantiene dentro del período estacional y determina el transporte de masa de larga duración en la bahía (Atkinson,1986). La circulación termohalina en los cuerpos costeros, en conjunción con las corrientes de marea y de deriva del viento, puede producir distintos elementos dinámicos como giros, surgencias y convergencias, los cuales juegan un papel importante en la evolución de los ecosistemas costeros y la dispersión de contaminantes.

\section{Área de estudio}

La Bahía de La Paz es la de mayor extensión en la costa este de la Península de Baja California, con $80 \mathrm{~km}$ de largo y hasta $35 \mathrm{~km}$ de ancho. La topografía de su fondo es variable (Cruz-Orozco et al., 1996), siendo la parte sur relativamente somera (hasta $40 \mathrm{~m}$ ), la parte norte profunda con la depresión Alfonso (hasta $450 \mathrm{~m}$ de profundidad), y con un canal bien definido en la boca principal de entre 220 y $320 \mathrm{~m}$ de profundidad. El intercambio de agua entre la bahía y el golfo se realiza a través de la boca principal y parcialmente por el Canal de San Lorenzo (hasta $18 \mathrm{~m}$ de profundidad) en la parte este de la bahía.

El clima de la región de La Paz es seco, semidesértico, con temperatura media anual entre $22^{\circ} \mathrm{C}$ y $24^{\circ} \mathrm{C}$, con régimen de lluvias en verano, y una precipitación media anual menor de $200 \mathrm{~mm}$ (Roden, 1958). En verano prevalece un sistema de brisas que ocasionan cambios diurnos del viento. Los vientos dominantes del sur se desarrollan de marzo a agosto mientras que de octubre a febrero los vientos provienen del noroeste. La Cordillera de Baja California es un obstáculo para que los vientos del noroeste y las brisas del Océano Pacífico penetren libremente a la bahía, existiendo también la influencia de tormentas tropicales del sur en verano y ciclones del norte en invierno. El área de estudio, la batimetría y la red de muestreo se ilustran en la figura 1.

\section{Métodos}

Durante las salidas al campo del 22 al 25 de octubre de 1997 y del 18 al 20 de agosto de 1999, se obtuvieron mediciones de las variables hidrológicas en una red de 54 estaciones en la Bahía de La Paz (fig. 1). Esta red también fue parcialmente recorrida los días 18 a 20 de noviembre de 1998. Las estaciones de la red fueron organizadas en nueve líneas con seis estaciones cada una. Los perfiles de temperatura, conductividad y presión se obtuvieron con un CTD marca SeaBird SB-25 (con resoluciones de temperatura de $0.001{ }^{\circ} \mathrm{C}$, conductividad de $0.00005 \mathrm{~S} / \mathrm{m}$ y profundidad de $0.00005 \%$ en el rango de 350 

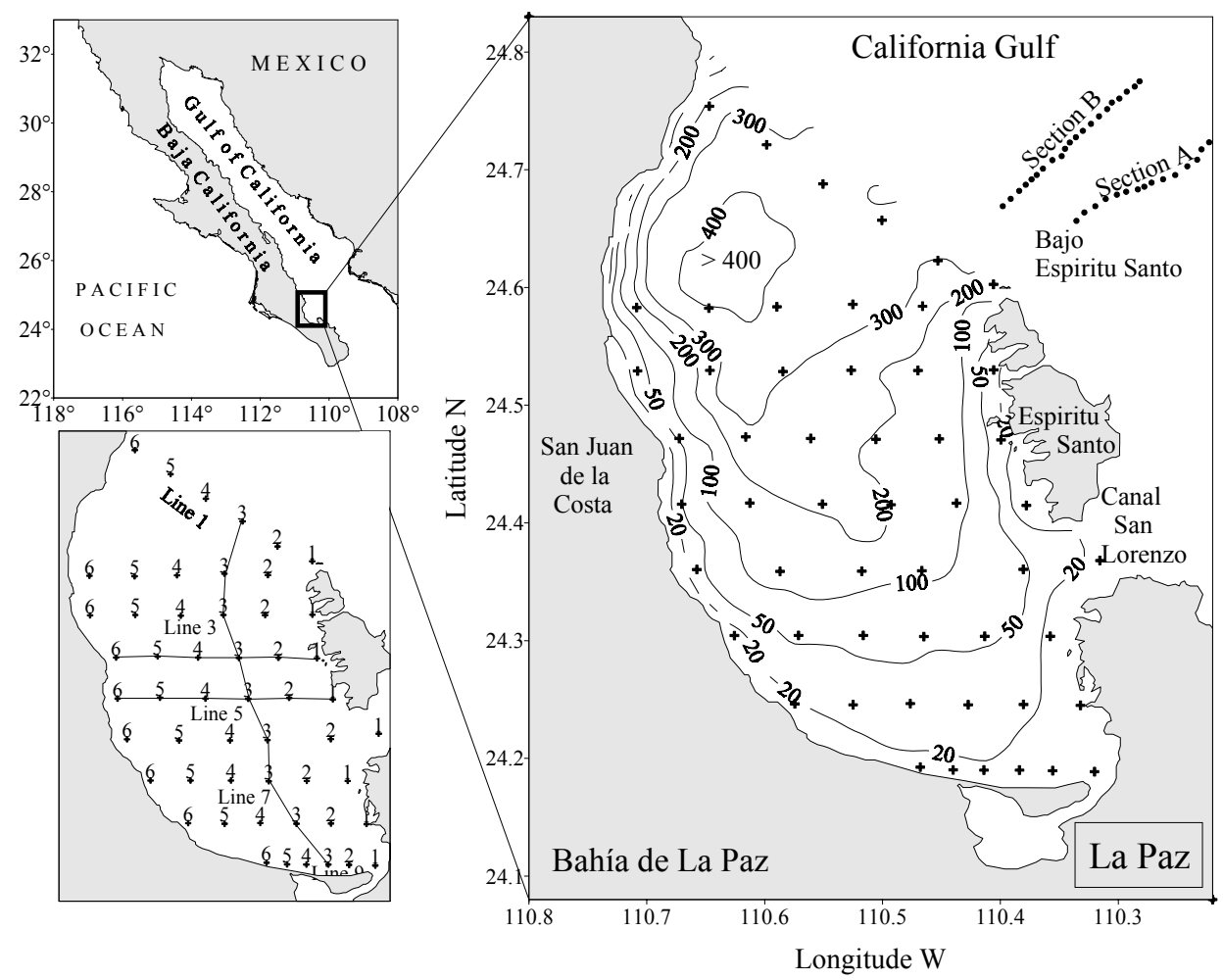

Figure 1. Map of Bahía de La Paz. Depth contours in meters. Sampling stations are shown in the lower left picture.

Figura 1. Mapa de la Bahía de La Paz. Contornos de profundidad en metros. Las estaciones de muestreo se encuentran abajo, a la izquierda.

salinity (relative units), density excess $\left(\rho-1000 ; \mathrm{kg} / \mathrm{m}^{3}\right)$ as well as the transverse (East-West) and longitudinal (north-south) vertical sections were determined. Bathymetric measurements were made with a Furuno echo sounder model FE-881 Mark II ( $1 \%$ accuracy at a $1500-\mathrm{m} / \mathrm{s}$ sound speed) on the same lines.

To accomplish the study, data obtained by the Centro de Investigaciones Biológicas (CIBNOR, La Paz) were used of the same variables, measured in July 1996 at the Espíritu Santo Shoal (area adjacent to the bay). The salinity and temperature profiles were recorded with a Sea Bird 25 CTD in two sections, A with 17 stations and B with 21 (fig.1).

The monthly averages of the meteorological variables during the sampling months are shown in table 1 (Monthly Metheorological Bulletins, La Paz Observatory of the National Water Comission). The mean monthly air temperature in October 1997 (peak of El Niño) was $1.5^{\circ} \mathrm{C}$ warmer than the mean of the past 30 years.

\section{Results}

\section{Stratification patterns}

In the three field trips, the vertical distributions of the thermohaline variables in the bay changed significantly. Figure $2 \mathrm{a}$ shows the comparison among the profiles of temperature, salinity and density excess at the station 4 (line 2) for the data $\mathrm{m})$. Las calibraciones se hicieron de acuerdo a las indicaciones del manual del equipo y la profundidad de muestreo fue de 70 a $350 \mathrm{~m}$. Los datos se registraron con una frecuencia de $8 \mathrm{~Hz} \mathrm{y}$ fueron promediados a cada metro de profundidad. Para conocer la variabilidad vertical fina en cada una de las capas promediadas se determinó la desviación estándar de los parámetros medidos. Se determinó la distribución horizontal de temperatura $\left[{ }^{\circ} \mathrm{C}\right]$, salinidad [unidades relativas] y exceso de densidad $(\rho-1000)\left[\mathrm{kg} / \mathrm{m}^{3}\right]$ a diferentes profundidades, así como las secciones verticales transversales (de este a oeste) y longitudinales (de norte a sur). En las mismas líneas se llevaron a cabo mediciones batimétricas con una ecosonda Furuno modelo FE-881 Mark II (con precisión del 1\% para la velocidad del sonido de $1500 \mathrm{~m} / \mathrm{s}$.).

Para completar el estudio se usaron mediciones de los mismos parámetros tomadas por el Centro de Investigaciones Biológicas (CIBNOR, La Paz) en el Bajo de Espíritu Santo (región adyacente a la bahía) en Julio de 1996. Los perfiles de salinidad y temperatura se registraron con el mismo CTD SeaBird SB-25 en dos secciones, la A con 17 estaciones y la B con 21 estaciones (fig. 1).

Los promedios mensuales de los parámetros meteorológicos de los meses de muestreo se muestran en la tabla 1 (Boletines Meteorológicos Mensuales, Observatorio de La Paz de la Comisión Nacional del Agua). La temperatura media mensual del aire en octubre de 1997 (máxima de El Niño) fue $1.5^{\circ} \mathrm{C}$ más cálida que el promedio de los últimos 30 años. 
Table 1. Monthly average of the meteorological parameters.

Tabla 1. Promedio mensual de variables meteorológicas.

\begin{tabular}{lcccccc}
\hline \multirow{2}{*}{ Month, year } & $\begin{array}{c}\text { Air temperature } \\
\left({ }^{\circ} \mathrm{C}\right)\end{array}$ & \multicolumn{2}{c}{ Wind $(\mathrm{m} / \mathrm{s})$} & Precipitation \\
\cline { 3 - 5 } & Mean-Max. & $\begin{array}{c}\text { Direction } \\
\text { Degree }\end{array}$ & $\begin{array}{c}\text { Velocity }(\mathrm{m} / \mathrm{s}) \\
\text { reignant-dominant }\end{array}$ & $\begin{array}{c}\text { Solar radiation } \\
\text { mm (Sum) }\end{array}$ & $\begin{array}{c}\text { Evaporation } \\
\text { calcm } / \text { day }\end{array}$ & mm (Sum) \\
\hline Junio, 1996 & $20.6-37.1$ & SSE & $2.2-4.3$ & 3.2 & & 273 \\
Julio, 1996 & $24.3-37.8$ & SSE & $2.1-4.2$ & 5.3 & & 282 \\
Agosto, 1996 & $25.3-35.8$ & SSE & $2.2-4.3$ & 108.5 & & 215 \\
Sep., 1997 & $25.8-35.4$ & SSE & $3.5-7.6$ & 77 & & 182 \\
Oct., 1997 & $22.9-33.6$ & NW & $5.2-10.7$ & 0 & & 197 \\
Nov., 1997 & $18.0-30.1$ & NW & $5.5-10.4$ & 1.4 & & 137 \\
Oct., 1998 & $20.9-35.3$ & NNW & $4.7-10.1$ & 0 & 389 & 213 \\
Nov., 1998 & $20.9-35.3$ & NNW & $5.3-10.1$ & 2 & 357 & 137 \\
Dic., 1998 & $12.0-25.6$ & NNW & $5.9-10.7$ & 0 & 317 & 117 \\
Julio, 1999 & $22.2-37.6$ & SSE & $2.1-4.0$ & 3.5 & 487 & 290 \\
Agosto, 1999 & $23.6-37.7$ & SSE & $2.2-4.2$ & 22 & 463 & 274 \\
Sep., 1999 & $23.6-36.1$ & SSW & $3.4-7.4$ & 20 & 408 & 218 \\
\hline
\end{tabular}

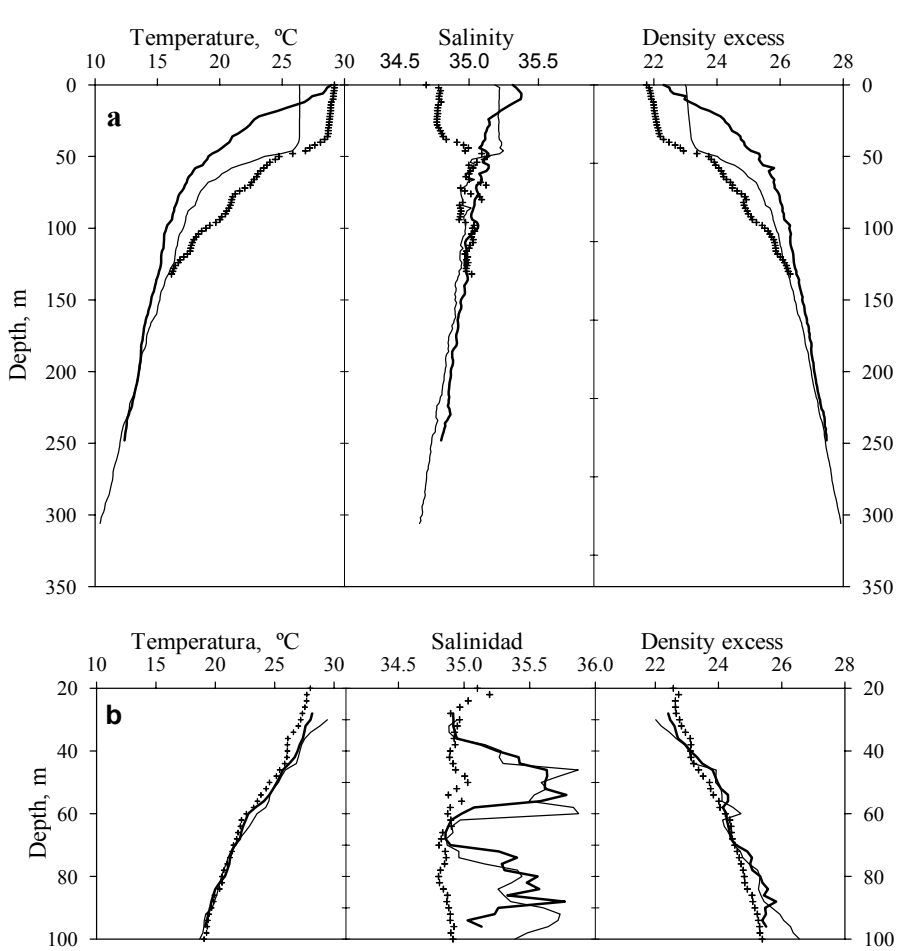

Figure 2. Profiles of temperature $\left({ }^{\circ} \mathrm{C}\right)$, salinity (relative units) and density excess $\left(\mathrm{Kg} / \mathrm{m}^{3}\right.$ ) at Bahía de La Paz (a: +++ Oct 1997; - Nov 98; - Aug 99) and at section B across the Espiritu Santo Shoal (b: +++ St.1; - St.10; - St. 19)

Figura 2. Perfiles de temperatura $\left({ }^{\circ} \mathrm{C}\right.$ ), salinidad (unidades relativas) y exceso de densidad $\left(\mathrm{kg} / \mathrm{m}^{3}\right)$ en la Bahía de La Paz (a: ${ }_{+++}$Oct./97; - Nov./ 98; - Ago./99) y en la sección B a través del Bajo de Espíritu Santo (b: ${ }_{+++}$Est. 1; - Est. 10; - Est. 19).

\section{Resultados}

Patrón de estratificación

En las tres salidas al campo las distribuciones verticales de los parámetros termohalinos en la bahía cambiaron significativamente. La figura 2a muestra la comparación entre los perfiles de temperatura, salinidad y exceso de densidad en la estación 4 (línea 2) para los datos de octubre de 1997, noviembre de 1998 y agosto de 1999. Los perfiles de temperatura muestran que en agosto se registró una termoclina continua desde la superficie hasta la profundidad de 80-90 m. En octubre y noviembre la distribución vertical en la bahía tuvo una capa de mezcla alrededor de los $45 \mathrm{~m}$ de profundidad. Para profundidades mayores de $150 \mathrm{~m}$ los parámetros termohalinos cambiaron poco y fueron similares a los medidos en otros muestreos. La comparación de las distribuciones a finales de octubre de 1997 y al principio de noviembre de 1998, muestran que la temperatura media en la capa de mezcla, en 1997, fue $2.5^{\circ} \mathrm{C}$ más alta y la salinidad fue menor en 0.4 (de aquí en adelante la salinidad no tiene dimensiones y, por recomendaciones de la UNESCO, es sólo una proporción) con respecto del muestreo de 1998. No obstante la salinidad aumenta en la época de verano (agosto de 1999) aumenta por la intensa evaporación (tabla 1). Durante cada salida de muestreo todos los perfiles tuvieron un patrón similar, con la única diferencia importante del grosor de la capa de mezcla.

Los perfiles típicos en las secciones externas de la bahía (Bajo de Espíritu Santo) se encuentran en la figura 2b. Las distribuciones de temperatura son parecidas en todas las estaciones y no presentan la capa superficial de mezcla. Los perfiles de salinidad en algunas estaciones muestran las capas 
from October 1997, November 1998, and August 1999. The temperature profiles show a continuous thermocline in August from the surface to a depth of $80-90 \mathrm{~m}$. In October and November, the vertical distribution in the bay had a mixed layer around 45-m depth. Below 150-m depth, the thermohaline variables changed little and were similar to the other samplings. The comparison of the distributions at the end of October 1997 and beginning of November 1998 shows that the mean temperature in the mixed layer in 1997 was $2.5^{\circ} \mathrm{C}$ higher and salinity was 0.4 lower with respect to the 1998 sampling (here and further salinity has no dimension according to UNESCO recommendation as a ratio). Even though salinity increased during summer (August 1999) because of the intense summer evaporation (table 1). During each field survey all the profiles had the same pattern with the only major difference being the thickness of the mixed layer.

The typical profiles of the outer sections of the bay (Espíritu Santo Shoal) are shown in figure 2b. The temperature distributions are similar for all the stations and do not show a mixed surface layer. The salinity profiles in some stations show more saline layers related to intrusion of other water caused by the complicated topography of the marine mountain of the Espíritu Santo Shoal, located between two deep canyons. Salinity in the intrusion layers has values up to almost 36.0 and the density profiles have unstable layers at the same depths.

\section{Three-dimensional thermohaline structure}

The analysis of the sampling data shows that the temperature variability range (from 10 to $29^{\circ} \mathrm{C}$ ) and its influence on the density field are greater than those of salinity (34.7 to 35.3), because of the more homogenous salinity distribution. Therefore, at the Bahía de La Paz temperature is the dominant factor in the formation of the thermohaline structure.

The horizontal distributions of temperature in August 1999 at the surface, 20-, 40-, and 60-m depth are shown in figure 3. At the surface, two wide lenses of relatively cold water were recorded; one $\left(<28.2^{\circ} \mathrm{C}\right)$ in the northwestern part close to the mouth, and another $\left(<28.1^{\circ} \mathrm{C}\right)$ in the southern part of the bay in front of the San Lorenzo Channel. The distribution at the 20-m depth is confirmed by the surface pattern. The distributions at the 40- and 60-m depths were more ordered, with a tongue of cold water in front of the main mouth. The eastern part of the mouth had high temperatures $\left(>28.8^{\circ} \mathrm{C}\right)$ due to the exit of warmer waters from the bay.

The horizontal temperature distributions for the same horizons in October 1997 are shown in figure 4. As in August, the surface temperature in the western part of the mouth was colder $\left(<29.0^{\circ} \mathrm{C}\right)$ than in the eastern one $\left(>29.4^{\circ} \mathrm{C}\right)$. Waters with temperatures similar to the latter extended from the entrance of the San Lorenzo Channel to the inside of the bay. There were two zones of maximum temperature, the largest one was in the center $\left(>29.4^{\circ} \mathrm{C}\right)$ and the other one was found at the head of the bay $\left(>29.5^{\circ} \mathrm{C}\right)$. At $20-\mathrm{m}$ depth, the distribution más salinas, que están relacionadas con la intrusión de distintos cuerpos de agua debido a la complicada topografía de la montaña marina del Bajo de Espíritu Santo, ubicada entre dos cañones profundos. La salinidad en las capas de intrusión tiene valores de hasta casi 36.0, y los perfiles de densidad tienen capas inestables en las mismas profundidades.

\section{Estructura termohalina tridimensional}

El análisis de los datos muestra que el rango de variabilidad de temperatura (de 10 a $29^{\circ} \mathrm{C}$ ) y su influencia sobre el campo de densidad fueron mayores que los de salinidad (de 34.7 a 35.4) debido a que la distribución de salinidad fue más homogénea. Por consiguiente, en la Bahía de La Paz la temperatura es el factor dominante en la formación de la estructura termohalina.

La figura 3 muestra la distribución horizontal de temperatura en agosto de 1999 en la superficie, 20, 40 y $60 \mathrm{~m}$ de profundidad. En la superficie se distinguen dos amplias lentes de agua relativamente frías, una $\left(<28.2^{\circ} \mathrm{C}\right)$ en la parte noroeste, cerca de la boca, y otra $\left(<28.1^{\circ} \mathrm{C}\right)$ al sur de la bahía, enfrente del Canal de San Lorenzo. La distribución a $20 \mathrm{~m}$ de profundidad confirma el patrón superficial. Las distribuciones a los 40 y $60 \mathrm{~m}$ son más ordenadas, con una lengüeta de agua fría frente a la boca principal. La zona este de la boca tuvo temperatura

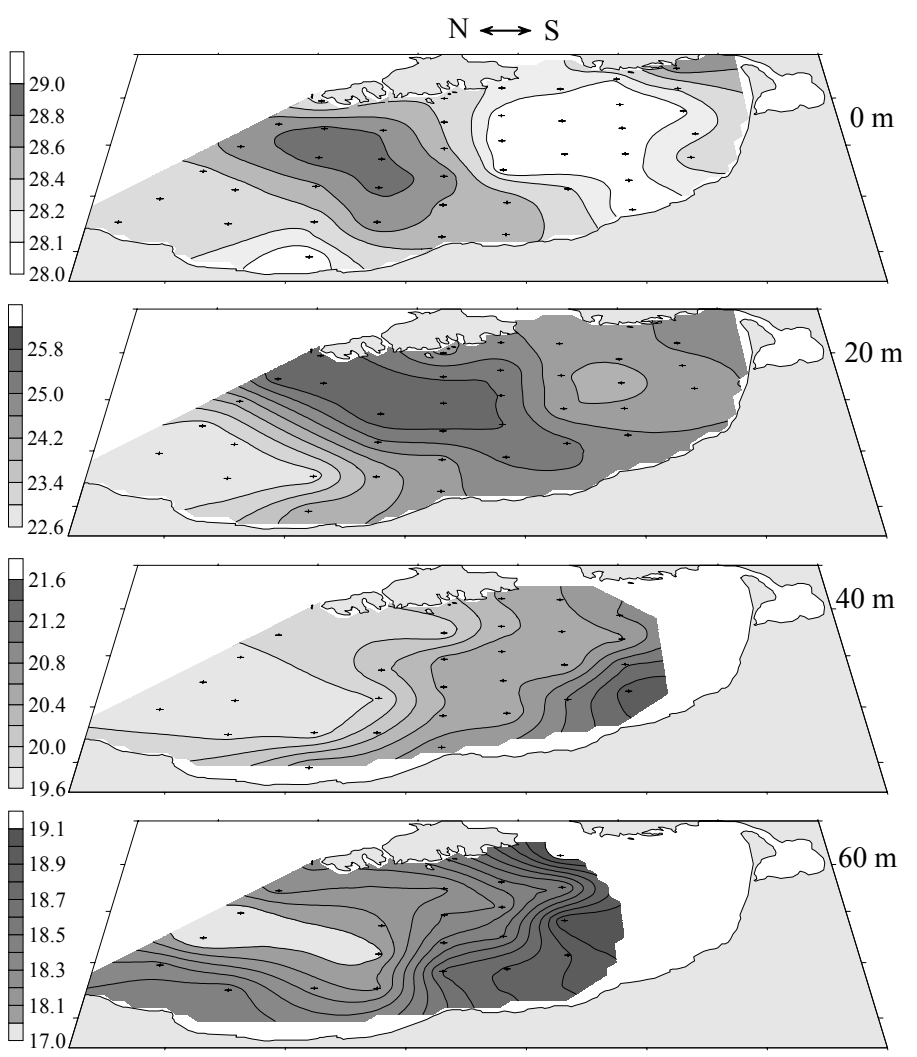

Figure 3. Temperature $\left({ }^{\circ} \mathrm{C}\right)$ distribution at Bahía de La Paz in Aug 1999. Figura 3. Distribución de temperaturas $\left({ }^{\circ} \mathrm{C}\right)$ en Bahía de La Paz, agosto de 1999. 

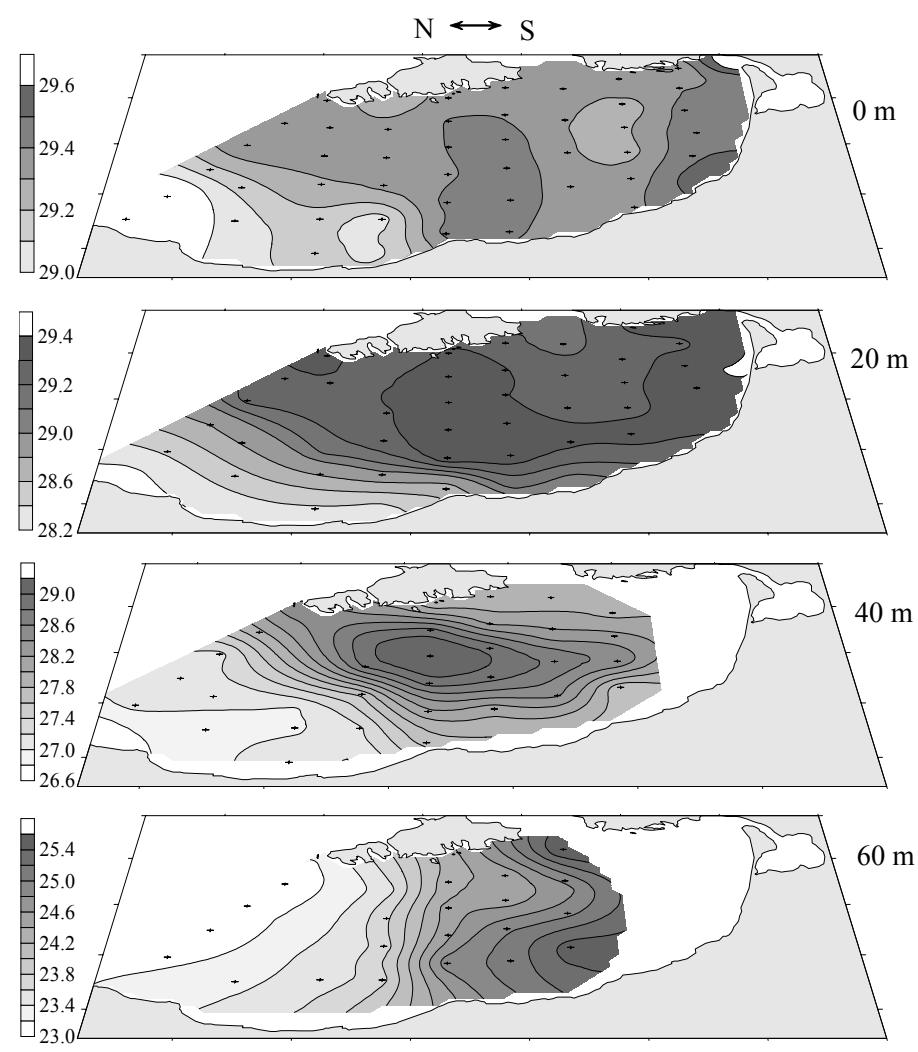

Figure 4. Temperature $\left({ }^{\circ} \mathrm{C}\right)$ distribution at Bahía de La Paz in Oct 1997. Figure 4. Distribución de temperaturas $\left({ }^{\circ} \mathrm{C}\right)$ en la Bahía de La Paz, octubre de 1997.

had a trend similar to that at the surface with the nucleus growing in the center. At 40-m depth, in the eastern extreme of the main mouth there was an intense horizontal temperature gradient with a temperature difference of $1.6^{\circ} \mathrm{C}$ (possibly because of a thermocline uplifting). The nucleus of maximum temperature remained in the center of the bay in front of the islands. In the $60-\mathrm{m}$ depth distribution of temperatures, the warm central nucleus does not exist but it is replaced by a South-North gradient.

Figure 5 shows the vertical sections of the thermohaline variables in the 60-m surface layer during August 1999; the longitudinal sections through station 4 of each line are to the left and, to the right are the transverse sections of line 5 . The longitudinal temperature distribution (fig. 5a, left) was practically uniform. Isohalines were convex between lines 3 and 6 (fig. 5b), which did not greatly affect the density distribution. The isopycnics were almost parallel and horizontal (fig. 5c). The transverse section (fig. 5, right) shows that the surface layer nearby the Espíritu Santo Island (right part) was warmer (slope of the isotherms) and there was a cold lens $\left(<28^{\circ} \mathrm{C}\right)$ at the surface in the center of the bay. Furthermore, isohalines show a noticeable slope in the same direction and, as a result, the isopycnics in the entire 60-m layer sank near the island. This non-uniformity of density should cause compensation currents. elevada $\left(>28.8^{\circ} \mathrm{C}\right)$ debido a la salida de aguas más cálidas de la bahía.

La distribución horizontal de temperatura para los mismos horizontes en octubre de 1997 se encuentra en la figura 4. Como en agosto, la temperatura superficial en la parte oeste de la boca fue más fría $\left(<29.0^{\circ} \mathrm{C}\right)$ que al este $\left(>29.35^{\circ} \mathrm{C}\right)$. Aguas con temperaturas similares a esta última, se extendieron desde la entrada del Canal de San Lorenzo hasta el interior de la bahía. Se localizaron dos zonas de temperatura máxima, la más grande al centro $\left(>29.4^{\circ} \mathrm{C}\right)$ y la otra en la cabecera de la bahía $\left(>29.5^{\circ} \mathrm{C}\right)$. A la profundidad de $20 \mathrm{~m}$ la distribución tenía una tendencia similar a la de la superficial con el núcleo central creciendo. A la profundidad de $40 \mathrm{~m}$, hacia el extremo este de la boca principal, se dió un intenso gradiente horizontal de temperatura con una diferencia de $1.6^{\circ} \mathrm{C}$ (posiblemente debido a un ascenso de la termoclina). El núcleo de máxima temperatura permaneció al centro de la bahía, frente a las islas. En la distribución de temperaturas a $60 \mathrm{~m}$ de profundidad el núcleo central cálido ya no existe, siendo éste reemplazado por un gradiente de sur a norte.

La figura 5 muestra las secciones verticales de parámetros termohalinos en la capa superficial de $60 \mathrm{~m}$ de la bahía en agosto de 1999. A la izquierda están las secciones longitudinales a través de la estación 4 de cada línea, y a la derecha las secciones transversales de la línea 5. La distribución longitudinal de temperatura (fig. 5a, izquierda) fue prácticamente uniforme; las isohalinas fueron convexas entre las líneas 3 y 6 (fig. 5b), lo que no influyó mucho en la distribución de densidad; las isopicnas fueron casi paralelas y horizontales (fig. 5c). La sección transversal (fig. 5, derecha) muestra que la capa superficial cerca de la Isla Espíritu Santo (parte derecha) estuvo más cálida (inclinación de las isotermas), y en la superficie al centro de la bahía existió un lente frío $\left(<28^{\circ} \mathrm{C}\right)$. Además, las isohalinas muestran una inclinación perceptible en la misma dirección y, como consecuencia, las isopicnas en toda la capa de $60 \mathrm{~m}$ de profundidad se hunden cerca de isla. Esta no uniformidad de densidad debe provocar las corrientes de compensación.

Las secciones relevantes de octubre de 1997 se presentan en la figura 6. A la izquierda se encuentra la sección longitudinal que pasa por la estación 3 de cada línea, y a la derecha está la sección transversal que pasa por la línea 4. En la capa superficial de mezcla (hasta $40 \mathrm{~m}$ de profundidad) la isoterma de $29^{\circ} \mathrm{C}$ tiene una inclinación ascendente hacia la parte norte, a profundidades mayores de $60 \mathrm{~m}$ la distribución de temperatura es horizontalmente uniforme (fig. 6a, izquierda). La variabilidad de la salinidad no fue significativa (fig. 6b) y no afectó mucho la distribución de densidad; las isopicnas tienen un patrón muy parecido a las isotermas. La peculiaridad de la sección transversal (fig. 6a, derecha) es que los gráficos presentan una concavidad en el centro de la sección, la cual indica la posible existencia de un giro anticiclónico. También es interesante la presencia significativa de aguas frías en la costa oeste de la bahía. 

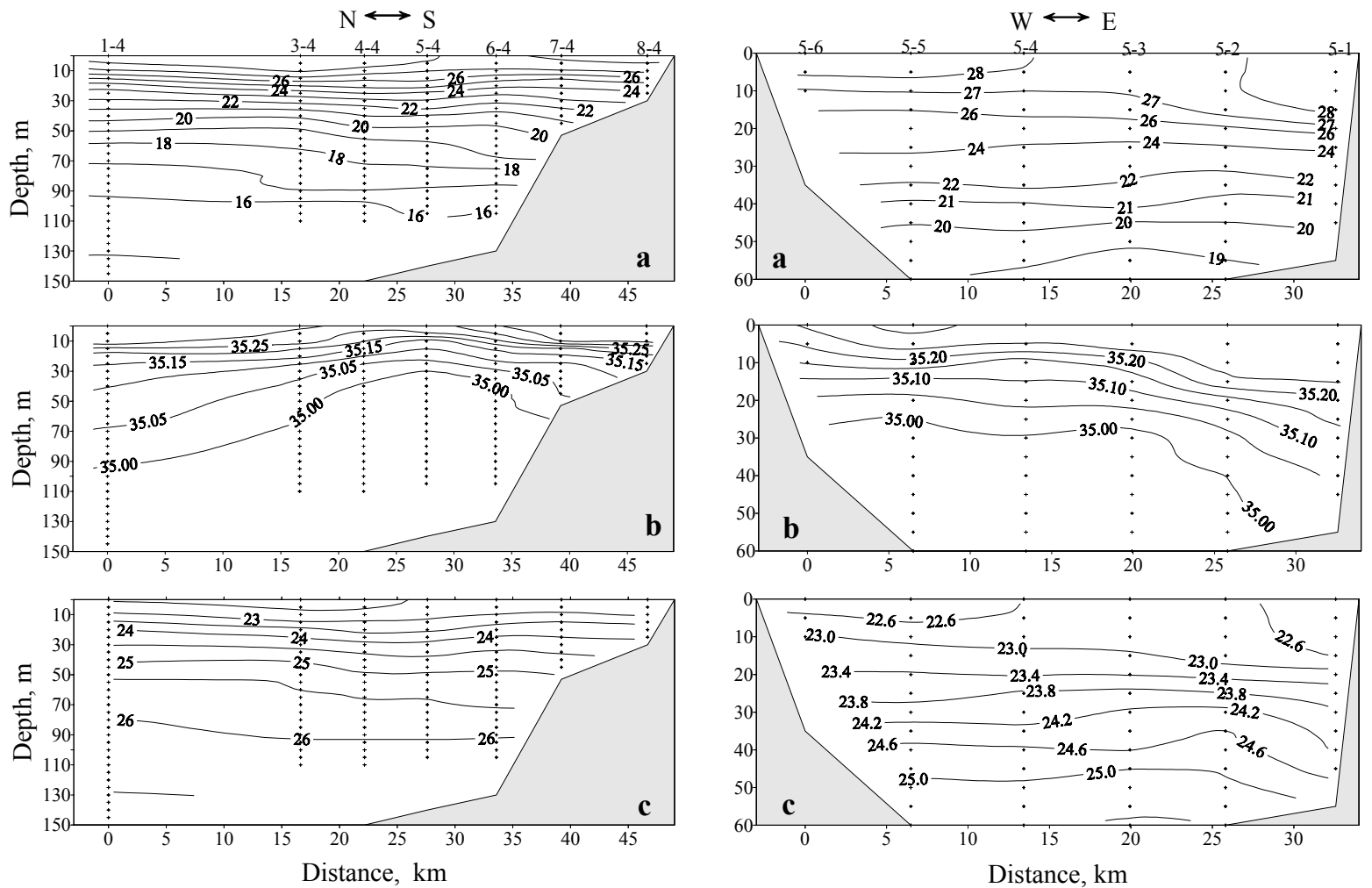

Figure 5. Vertical sections of Bahía de La Paz of (a) temperature $\left({ }^{\circ} \mathrm{C}\right)$, (b) salinity (ups) and (c) density excess $\left(\mathrm{Kg} / \mathrm{m}^{3}\right)$ in Aug 1999. Longitudinal section across station no. 4 of each line is on the left, transverse section (line 5 ) is on the right.

Figure 5. Secciones verticales en la Bahía de La Paz: (a) temperatura $\left({ }^{\circ} \mathrm{C}\right)$, (b) salinidad (unidades relativas) y $(\mathbf{c})$ exceso de densidad $\left(\mathrm{kg} / \mathrm{m}^{3}\right)$ en agosto de 1999. A la izquierda la sección longitudinal a través de la estación 4 de cada línea, a la derecha la sección transversal que pasa por la línea 5.

The relevant sections of October 1997 are shown in figure 6. To the left is the longitudinal section that passes through stations 3 of each line and to the right is the transverse section that passes through line 4 . At the surface mixed layer (up to $40-\mathrm{m}$ depth), the $29^{\circ} \mathrm{C}$ isotherm has a rising slope in the northern part. At depths greater than $60 \mathrm{~m}$, the temperature distribution is horizontally uniform (fig. 6a, left). The variability in salinity was not significant (fig. 6b) and did not greatly affect the density distribution; the isopycnics have a pattern similar to that of the isotherms. The peculiarity of the transverse section (fig. 6a, right) is that the plots have a concavity towards the center of the section, which indicates the possible existence of an anticyclonic gyre. Also interesting is the significant presence of cold waters in the west part of the bay.

\section{Discussion}

Bahía de La Paz is a deep coastal body with a rather wide mouth. The type of thermohaline structure and stability of such water-bodies are determined by the superimposing of two effects, the dynamic exchange of the water through their mouth and the local thermodynamic changes under atmospheric processes (insolation, evaporation, precipitation and mixing). It is natural to expect in the deep layers (northern part of the bay) the influence of the Gulf of California waters to be more

\section{Discusión}

La Bahía de La Paz es un cuerpo costero profundo de boca amplia. El tipo de estructura termohalina y la estabilidad en dicho cuerpo son determinados por la superposición de dos efectos: el intercambio dinámico de agua a través de la boca y los cambios termodinámicos locales en la capa superficial sometida a procesos atmosféricos (insolación, evaporación, precipitación y mezcla). Es natural esperar que en las capas profundas (parte norte de la bahía) la influencia de las aguas del Golfo de California sea más intensa y en la parte somera (sur de la bahía) los procesos locales sean los que dominen.

Los perfiles de temperatura y salinidad (fig. 2a) muestran que los cambios estacionales más significativos se registraron en la capa de los primeros $100 \mathrm{~m}$ de profundidad. En julioagosto, por la fuerte radiación solar $\left(400-500 \mathrm{cal} / \mathrm{cm}^{2} / \mathrm{día}\right.$, tabla 1) se forma la intensa termoclina desde la superficie, con un gradiente vertical de temperatura que alcanza $0.3^{\circ} \mathrm{C} / \mathrm{m}$ en los primeros $20 \mathrm{~m}$ (fig. 2a, cruces). Por la intensa evaporación se forma la capa superficial de 15-20 m más salina, manteniéndose la estabilidad vertical de la columna gracias al gradiente de temperatura. Los vientos débiles (tabla 1) no provocan una mezcla vertical intensa que permita formar una capa gruesa superficial homogénea, sino que este proceso se desarrolló hasta fines de agosto. A principios de septiembre y, más tarde 

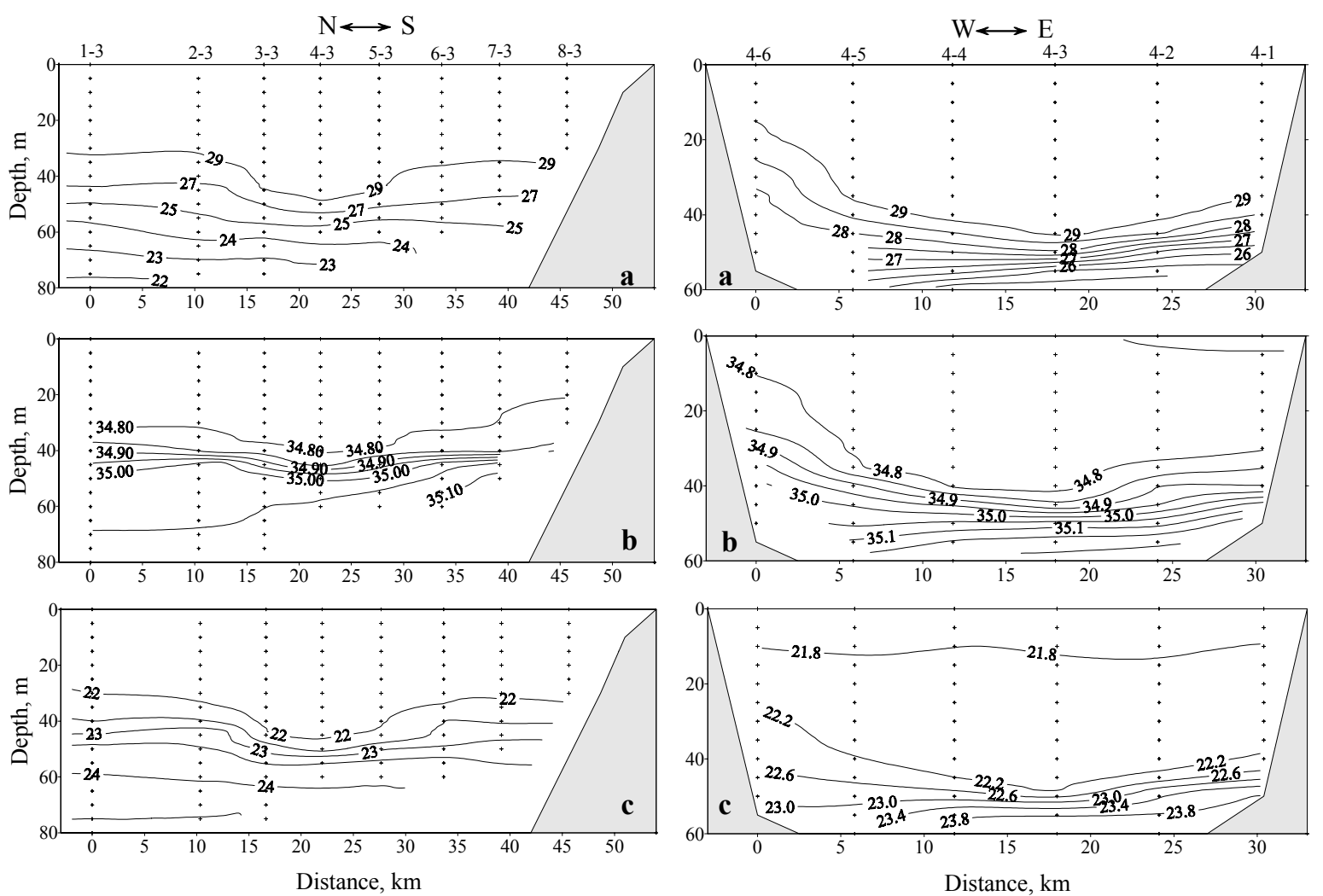

Figure 6. Vertical sections of the Bahía de La Paz of (a) temperature $\left({ }^{\circ} \mathrm{C}\right)$, (b) salinity (ups) and (c) density excess $\left(\mathrm{Kg} / \mathrm{m}^{3}\right)$ in Oct 1997. Longitudinal section across station No. 3 of each line is on the left, transversal section (line 4 ) is on the right.

Figure 6. Secciones verticales en la Bahía de La Paz: (a) temperatura $\left({ }^{\circ} \mathrm{C}\right)$, (b) salinidad (unidades relativas) y $(\mathbf{c})$ exceso de densidad $\left(\mathrm{kg} / \mathrm{m}^{3}\right)$ en octubre de 1997. A la izquierda la sección longitudinal a través de la estación 3 de cada línea, a la derecha la sección transversal que pasa por la línea 4.

intense and, the shallow part (southern part of the bay) to be dominated by local processes.

The temperature and salinity profiles (fig. 2a) show that the most significant seasonal changes were recorded in the first $100 \mathrm{~m}$ from July to August. Because of the high solar radiation (400-500 cal $/ \mathrm{cm}^{2} /$ day, table 1$)$, an intense thermocline is formed from the surface, with a vertical temperature gradient that reaches $0.3^{\circ} \mathrm{C} / \mathrm{m}$ in the upper $20 \mathrm{~m}$ (fig. $2 \mathrm{a}$, crosses). Because of the intense evaporation, a surface layer of 15-20 m is more saline, maintaining the vertical stability of the column with the temperature gradient. The weak winds (table 1) do not cause intense vertical mixing to form a thick homogenous surface layer, but this process developed until the end of August. At the beginning of September, and later during the hurricane season, vertical mixing increases due to the intensification of the wind up to $10 \mathrm{~m} / \mathrm{s}$ and to the impact of hurricanes (2-3 during autumn), developing the surface mixed layer up to $45-50$ $m$ depth (passing from the thick line to the thin one, fig. $2 a$ ). Within this process, the high salinity of the surface layer formed by the summer evaporation also helps to vertical mixing. As the autumn progressed the surface mixed layer was formed, which was recorded in October and November.

The stratification transformation varies from one year to the next. The mean temperature in the mixed layer at the end of durante la temporada de tormentas, la mezcla vertical se incrementa por la intensificación del viento hasta $10 \mathrm{~m} / \mathrm{s}$ y por el impacto de los huracanes (de 2-3 durante otoño), formándose la capa superficial de mezcla hasta $\operatorname{los} 45-50 \mathrm{~m}$ de profundidad (pasando de la línea gruesa a la delgada, fig. 2a). Durante este proceso la elevada salinidad en la capa superficial formada durante la evaporación de verano también ayuda a la intensificación de la mezcla vertical. Conforme avanza el otoño se forma la capa superficial de mezcla, la cual fue registrada en octubre y noviembre.

Los cambios en la estratificación tienen variaciones de un año al otro. La temperatura media en la capa de mezcla a fines de octubre de 1997 fue $2.5^{\circ} \mathrm{C}$ más alta que a principios de noviembre de 1998 (fig. 2a), lo que fácilmente se explica por la influencia de El Niño de 1997 con el aumento de temperatura superficial de la región adyacente del golfo que intercambia agua con la bahía. La salinidad en la capa superficial en octubre de 1997 fue 0.4 menor que la de noviembre de 1998, hecho que no puede explicarse por la precipitación del mes anterior (tabla 1). El área del escurrimiento pluvial es menor que el área de la bahía y no puede aumentar la descarga por lluvia en más del $50 \%$. No obstante, el cálculo de la dilución proporcional muestra que, para disminuir la salinidad de 35.0 hasta 34.6 en los primeros 50 metros de profundidad, se requieren $570 \mathrm{~mm}$ 
October 1997 was $2.5^{\circ} \mathrm{C}$ higher than that at the beginning of November 1998 (fig. 2a). This is easily explained by the influence of the $1997 \mathrm{El}$ Niño with the increase in the surface water temperature in the region adjacent to the gulf that exchanges water with the bay. Salinity in the surface layer in October 1997 was 0.4 lower than that of November 1998. This cannot be explained by the precipitation of the previous month (table 1). The rain runoff area is smaller than the area of the bay and the total bay runoff cannot increase by more than $50 \%$. However, the calculation of the proportional dilution shows that for salinity to decrease from 35.0 to 34.6 in the first $50 \mathrm{~m}$ of depth, $570 \mathrm{~mm}$ of rainfall are required (without considering the evaporation effect). The precipitation in September 1997 was only $77 \mathrm{~mm}$, therefore, it is impossible to explain the low salinity in the surface layer only by the local precipitation, and de precipitación (sin tomar en consideración el efecto de evaporación), cuando la precipitación en septiembre de 1997 fue sólo de $77 \mathrm{~mm}$. Por consiguiente, es imposible explicar la baja salinidad en la capa superficial solamente con la precipitación local, por lo que se sugiere que este efecto fue creado por el intercambio de agua con regiones adyacentes a través de la boca. Blanco-Betancourt (1996) mostró que en la zona de entrada del Golfo de California existen algunos giros que pueden transportar hacia la bahía aguas tropicales superficiales de menor salinidad que las aguas del golfo. Collins et al. (1997) y Castro et al. (2000) en todas sus observaciones encontraron una circulación ciclónica en la boca del Golfo de California y proponen un sistema de circulación para la capa superior de $200 \mathrm{~m}$, en el que las aguas salen del golfo frente a las costas de BCS y entran a él frente a las costas de Sinaloa.
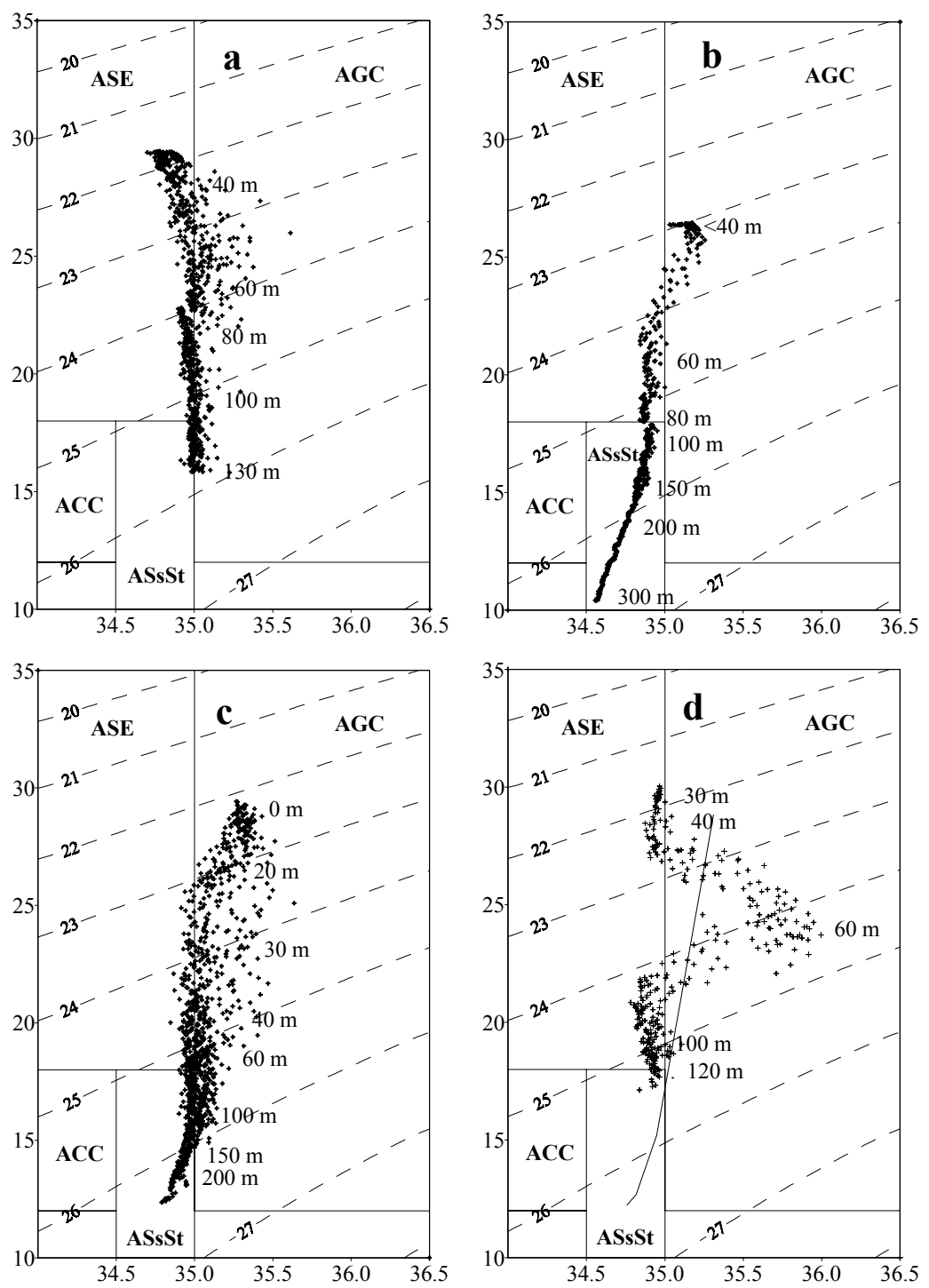

Figure 7. T-S diagrams of the Bahía de La Paz in (a) Oct 1997, (b) Nov 1998, (c) Aug 1999 and (d) line A outside the bay in Jul 1996, where the solid line shows an average profile for the survey in Aug (c).

Figura 7. Diagramas T-S (temperatura en ${ }^{\circ} \mathrm{C}$ y salinidad en ups) de la Bahía de Paz en: (a) octubre de 1997, (b) noviembre de 1998, (c) agosto de 1999 y (d) la línea A fuera de la bahía en Julio de 1996 donde la línea sólida muestra el perfil promedio del muestreo de agosto (c). 
it is suggested that this effect was created by the water exchange with adjacent regions through the mouth. Blanco-Betancourt (1996) showed that, at the entrance to the Gulf of California, there are gyres that can transport tropical surface waters to the bay that are less saline than the waters of the gulf. Collins et al. (1997) and Castro et al. (2000) in all their observations found a cyclonal circulation in the mouth of the Gulf of California, and they propose a circulation system for the upper layer of $200 \mathrm{~m}$ in which waters leave the gulf in front of the coasts of BCS and enter it in front of the coasts of Sinaloa.

At depths greater than $150 \mathrm{~m}$, the vertical distribution of the thermohaline variables has few temporal variations during the summer and it is almost not influenced by the changes in the surface layer. Therefore, the deep water of the bay maintains its mean thermohaline characteristics and can be characterized as a more or less stable water mass from summer to autumn. We need to analyze the origin of this waterbody. Has this water been modified by local processes within the bay or does it enter from the open ocean through the mouth? To clarify this point, T-S diagrams were constructed for all the samples based on the profiles measured in the deep part of the bay (fig. 7). The classification of the water masses was made according to the criteria used by Torres-Orozco (1993). It is evident that the use of the term "water masses" is not physically correct for coastal bodies because of their high variability, but in some cases the T-S diagrams can be useful to identify the water as a point of reference. The T-S diagram of October 1997 (fig. 7a) in its wide range of temperature conserves salinity around 35, balanced between Equatorial Surface Water (ASE) and Gulf of California Water (AGC). The surface layer (up to $40 \mathrm{~m}$ ) has less saline waters than the AGC and is in the range of ASE. Wirtki (1967) and Roden (1872) noticed that waters with ASE characteristics are found in the surface layer at the entrance of the gulf (near Bahía de La Paz).

In November 1998 (fig. 7b) the surface layer up to $50 \mathrm{~m}$ depth had AGC characteristics, and from 80 to $300 \mathrm{~m}$ waters were in the range of Subtropical Subsurface Water (ASsSt). In August 1999 (fig. 7c) the T-S diagram follows the previous pattern, with wider salinity variations (34.8-35.5). The most important aspect is that the characteristics of the deep waters of the bay were in the range of ASsSt and not in that of AGC. The results suggest that the deep waterbody of the bay is formed with waters of the gulf locally transformed during the annual cycle. In summer, the surface layer accumulates heat, and the salt content changes (by precipitation and evaporation); the winds and hurricanes in autumn distribute the heat, forming the thick mixed layer (up to $50 \mathrm{~m}$ ). Finally the thermohaline variables of the deep waterbody of the bay, with depths greater than $100 \mathrm{~m}$, are transformed during the winter by cooling and vertical deep mixing processes.

In the external section of the bay, in July 1997 (fig. 7d), T-S diagrams show that in the surface $(<45 \mathrm{~m})$ and deep ( $>90 \mathrm{~m})$ layers the salinity values were similar to those inside the bay (around 35.0), whereas between 50 and $80 \mathrm{~m}$ depth, there were more saline waters (up to 36.0) with characteristics definitely belonging to AGC. These waters can enter the bay and affect the distribution of salt in its northern part.
A profundidades mayores de $150 \mathrm{~m}$, la distribución vertical de los parámetros termohalinos tiene pocas variaciones temporales durante el verano y casi no está influenciada por los cambios en la capa superficial. Por consiguiente, el cuerpo de agua profundo de la bahía mantiene sus características termohalinas medias y puede caracterizarse como una masa de agua más o menos estable durante todo verano-otoño. Es necesario analizar el origen de este cuerpo de agua iSe han modificado estas aguas por procesos locales dentro de la bahía o han entrado del océano abierto a través de la boca? Para aclarar este asunto se construyeron los diagramas T-S para todos los muestreos en base a los perfiles medidos en la parte profunda de la bahía (fig. 7). La clasificación de las masas de agua se hizo de acuerdo al criterio utilizado por Torres Orozco (1993). Es evidente que el uso del término "masas de agua" no es físicamente correcto para los cuerpos costeros debido a su gran variabilidad, sin embargo, en algunos casos las diagramas T-S pueden ser de utilidad para la identificación del agua como punto de referencia. El diagrama T-S de octubre de 1997 (fig. 7a) en su amplio rango de temperaturas conserva una salinidad alrededor de 35, balanceada entre Agua Superficial Ecuatorial (ASE) y Agua del Golfo de California (AGC). La capa superficial (hasta $40 \mathrm{~m}$ ) tiene aguas menos salinas que el AGC, y se encuentra en al rango de ASE. Wirtki (1967) y Roden (1972) notaron que en la capa superficial de la zona de entrada del golfo (cerca de la cual se ubica la Bahía de La Paz) las aguas presentan características de ASE .

En noviembre de 1998 (fig. 7b) la capa superficial hasta los $50 \mathrm{~m}$ de profundidad tuvo características del AGC y, a partir de los $80 \mathrm{~m}$ hasta $300 \mathrm{~m}$, las aguas se encuentran en el rango del Agua Subsuperficial Subtropical (ASsSt). En agosto de 1999 (fig. 7c) el diagrama T-S básicamente sigue el patrón anterior, con variaciones más amplias en la salinidad (34.8-35.5). El aspecto más importante es que las características de las aguas profundas de la bahía estuvieron en el rango del ASsSt, y no en el de AGC. Los resultados sugieren que el cuerpo profundo de agua de la bahía se forma con aguas del golfo localmente transformadas durante el ciclo anual. En verano, la capa superficial acumula el calor y cambia el contenido de sal (por precipitación y evaporación); los vientos y huracanes de otoño distribuyen el calor formando la capa gruesa de mezcla (hasta $50 \mathrm{~m}$ ). Finalmente, los parámetros termohalinos del cuerpo de agua profunda de la bahía, con profundidades mayores de 100 $\mathrm{m}$, se transforman durante el invierno por procesos de enfriamiento y mezcla vertical profunda.

En las secciones externas de la bahía, en julio de 1997 (fig. 7d) los diagramas T-S muestran que en las capas superficial $(<45 \mathrm{~m})$ y profundidad $(>90 \mathrm{~m})$ los valores de salinidad son parecidos a los internos de la bahía (alrededor de los 35), mientras que en la capa entre los 50 y $80 \mathrm{~m}$ de profundidad las aguas son más salinas (hasta 36.0 ) y sus características pertenecen definitivamente al AGC. Estas aguas pueden penetrar a la bahía y afectar la distribución de sal en su parte norte.

La estructura termohalina horizontal es no uniforme y puede caracterizarse como baroclínica. La peculiaridad más 


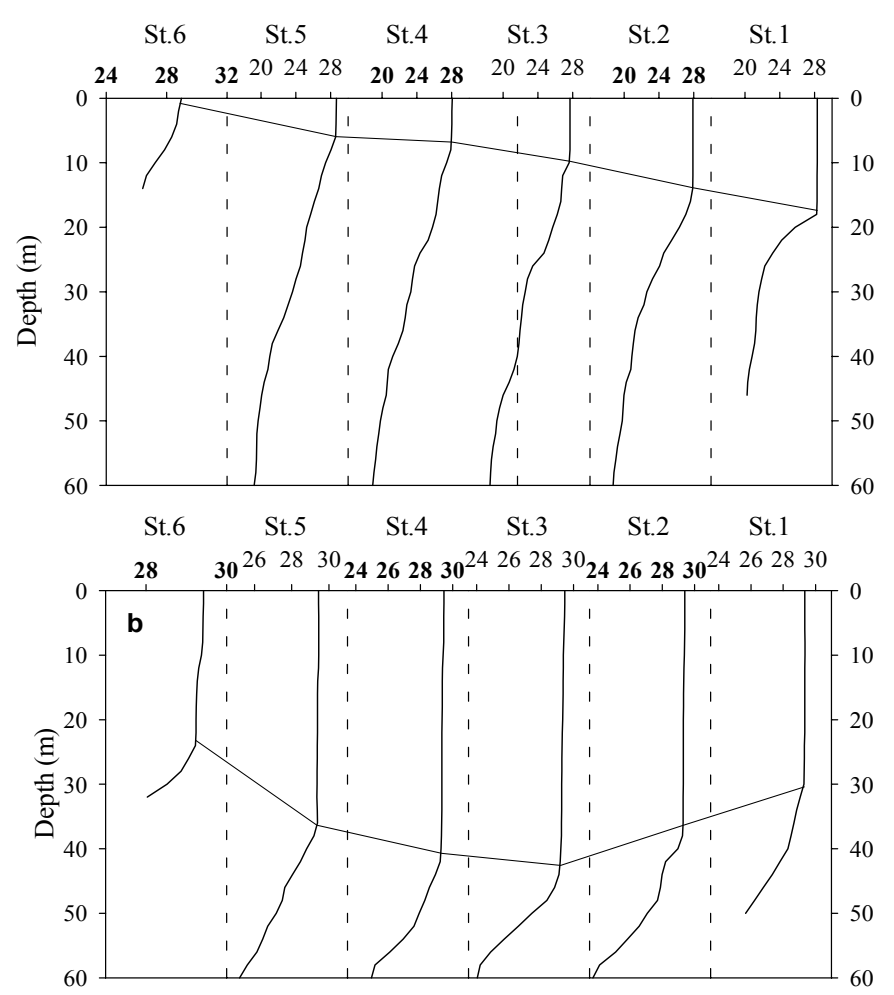

Figure 8. Well-mixed surface layer at the line 5 section: (a) temperature $\left({ }^{\circ} \mathrm{C}\right)$ profiles of Aug 1999, (b) temperature $\left({ }^{\circ} \mathrm{C}\right)$ profiles of Oct 1997 . The thin lines represent the low frontier of the mixture layer

Figura 8. Capa superficial bien mezclada en la sección de la línea 5: (a) perfiles de temperatura $\left({ }^{\circ} \mathrm{C}\right.$ ) de agosto de 1999 , (b) perfiles de temperatura $\left({ }^{\circ} \mathrm{C}\right)$ de octubre de 1997 . Las líneas claras representan la frontera inferior de la capa de mezcla.

Horizontally, the thermohaline structure was not uniform and it can be characterized as baroclynic. The most noticeable peculiarity was the wide cold zone in the western part of the main mouth. This suggests that, in the first $40 \mathrm{~m}$ of depth, there was a permanent flow of cold water from the Gulf of California, whereas the warm waters exit through the eastern part of the mouth (figs. 3 and 4). This intrusion of cold, dense water from the open ocean caused an inclination of the density field in the transverse sections of the bay (August 1999, fig. 5c, right). The isopycnics rise significantly in the westerly direction and induce the compensation current in the deep layers. Another possible explanation for the cold surface zone in the northwestern part of the bay is the upwelling effect forced by winds from the SE, which blow constantly. However, table 1 does not show a sufficient wind intensity or permanence in just one direction. In the southern part of the bay there was another relatively cold and stable zone, resulting from the intrusion of adjacent waters through the San Lorenzo Channel.

In October 1997, a lens of warm water was located at the surface layer in the center of the bay ( $<50 \mathrm{~m}$ depth) (fig. 4). Its location is evident by the concavity in the vertical sections (fig. 6). This pattern of isopycnics is usually related to a anticyclonic vorticity structure (Stern, 1975) caused by density currents along with the topography of the bay. This vorticity notable es la amplia zona fría en la parte oeste de la boca principal. Esto sugiere que, en los primeros 40 metros de profundidad, existe un flujo permanente de agua fría del Golfo de California mientras que las aguas cálidas salen por la parte este de la boca (figs. 3 y 4). Dicha intrusión de agua fría y densa del mar abierto provoca una inclinación del campo de densidad en las secciones transversales de la bahía (agosto de 1999, fig. 5c, derecha). Las isopicnas ascienden en forma significativa en dirección oeste e inducen la corriente de compensación en las capas profundas. Otra posible explicación de la zona superficial fría en la parte noroeste de la bahía es el efecto de surgencias forzadas por los vientos del sureste que soplan constantemente. Sin embargo, la tabla 1 no muestra que la intensidad de viento ni su permanencia en una sola dirección sean suficientes. En la parte sur de la bahía se localiza otra zona relativamente fría y estable como resultado de la intrusión de las aguas adyacentes a través del Canal de San Lorenzo.

En octubre de 1997, al centro de la bahía en la capa superficial $(<50 \mathrm{~m})$ se ubicó un lente del agua cálida (fig. 4), su localización es muy evidente por la concavidad de las secciones verticales (fig. 6). Este patrón de isopicnas está usualmente relacionado con una estructura de vorticidad anticiclónica (Stern, 1975) provocada por las corrientes de densidad con la topografía real de la bahía. Esta vorticidad puede mantenerse por el flujo de entrada en la parte oeste de la boca, formando un meandro a la altura de la línea 3 y saliendo por la parte este de la boca.

Las variaciones de densidad fueron más pronunciadas en la capa superior de 40-50 m, y la profundidad de la capa de mezcla varía significativamente en la horizontal (fig. 8). En agosto de 1999 la capa de mezcla se encontraba en estado de formación e iniciaba desde los $5 \mathrm{~m}$ de profundidad en la parte oeste y desde los 17-18 m en la parte este. En octubre de 1997 la capa de mezcla estaba bien formada y tenía una concavidad bien desarrollada. Además de una explicación dinámica del origen de esta concavidad, la distribución similar a la de la figura 8 puede ser causada por la no uniformidad de la mezcla vertical. Si durante el período de formación de la capa de mezcla, el viento es espacialmente no uniforme (por ejemplo, debido a la protección de la costa a lo largo de la bahía), también la redistribución vertical de calor será no uniforme. Entonces el contenido calorífico de la columna vertical del agua permanecería constante y no provocaría las corrientes de densidad en las capas profundas.

Con el objeto de aclarar este asunto, se calcularon las variaciones de la topografía dinámica (como $M=\int \alpha(z) d z$, siendo $\alpha$ el volumen específico y $z$ la profundidad) con un nivel de referencia de $50 \mathrm{~m}$ en todas las estaciones. La distribución espacial de este parámetro que representa la presión hidrostática a $50 \mathrm{~m}$ de profundidad, para agosto de 1999 y octubre de 1997, se muestra en la figura 9. A pesar de las diferentes condiciones meteorológicas, el patrón de distribución de masa es muy parecido en ambos casos, con la diferencia de que en la primera distribución se observa un fuerte gradiente que induce un intenso flujo y, por la geometría de la cuenca, al noroeste se 

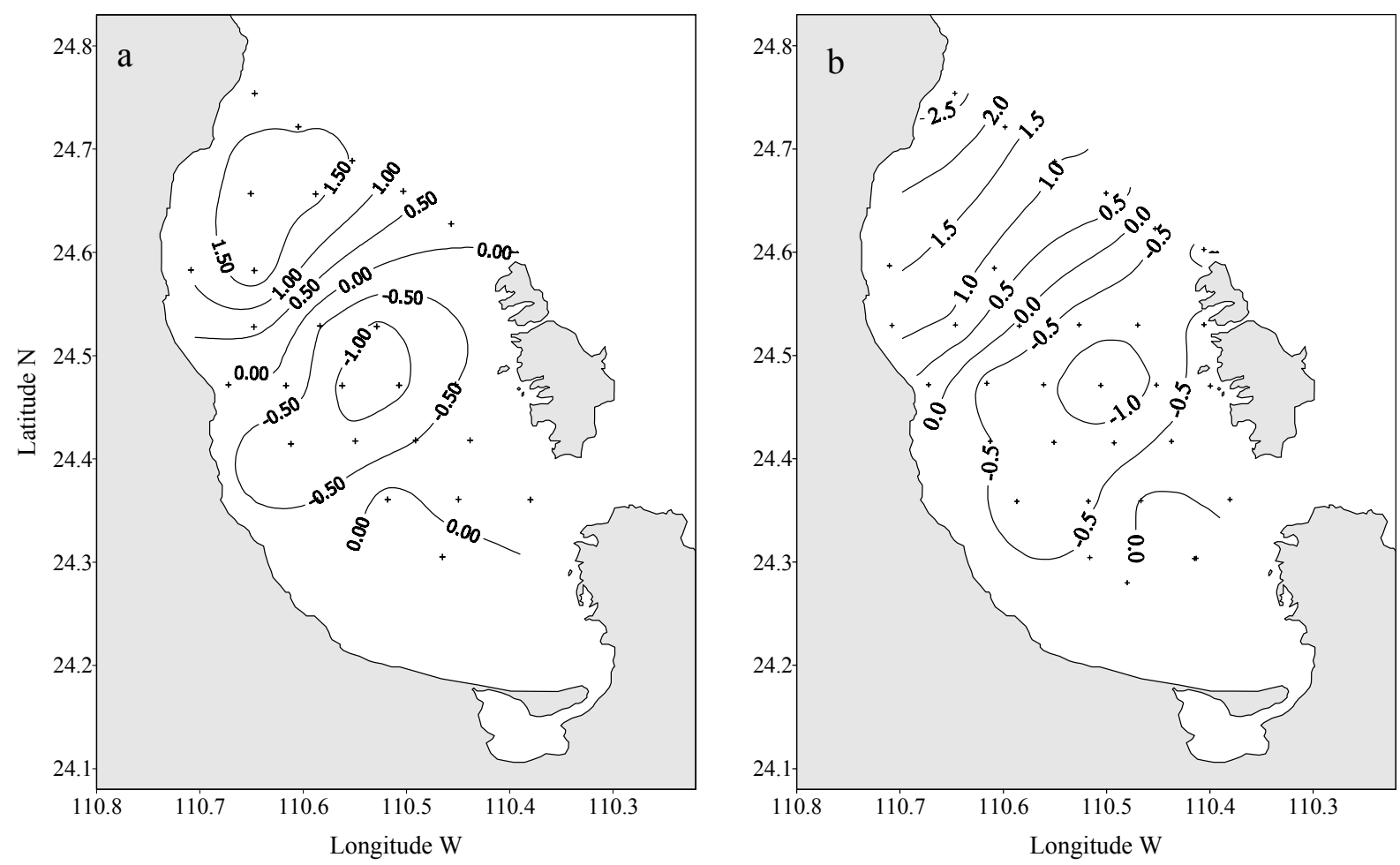

Figure 9. Dynamic topography $\left(\mathrm{m}^{2} \mathrm{~s}^{-2}\right)$ with a reference level of $50 \mathrm{~m}$ : (a) August 1999, (b) October 1997.

Figura 9. Altura dinámica $\left(\mathrm{m}^{2} \mathrm{~s}^{-2}\right.$ ) con nivel de referencia de $50 \mathrm{~m}$ de profundidad: (a) en agosto de 1999, (b) en octubre de 1997.

can persist because of the input flow in the western part of the mouth that forms a meander at the height of line 3 and exits through the eastern part of the mouth.

The density variations were more significant in the upper 40-50-m layer and the depth of the mixed layer widely varied horizontally (fig. 8). In August 1999, the stable mixed layer was in state of formation and began from the 5-m depth in the western part to $17-18 \mathrm{~m}$ in the eastern part. In October 1997, the mixed layer was well formed and had a well-developed concavity. Besides a dynamic explanation of the origin of this concavity, the distribution similar to that of figure 8 may be caused by the horizontal nonuniformity of vertical mixing. If during the formation period of the mixed layer, the wind is spatially non-uniform (due to the shore protection along the bay, for example), the vertical redistribution of heat will also be non-uniform. Then, the heat content in the vertical water column will remain constant and will not cause density currents in the deep layers.

In order to clarify this point, the dynamic topography variations were calculated (as $M=\int \alpha(z) d z$, being $\alpha$ the specific volume and $z$ the depth) with a reference level of $50 \mathrm{~m}$ at all stations. The spatial distributions of this parameter, which represents the hydrostatic pressure at $50 \mathrm{~m}$ depth, are shown in figure 9 for August 1999 and October 1997. Despite the different meteorological conditions, the mass distribution pattern is similar in both cases, with the difference that in the first distribution a strong gradient is observed that induces an intense flow and, given the geometry of the basin, a second, forma un segundo vórtice ciclónico no estable. Dentro de la bahía se localizó un núcleo de menor densidad centrado en la línea 4 , el cual es una condición para la existencia de un vórtice anticiclónico. Dicha estructura, así como la distribución de la profundidad de la capa superficial de mezcla, no pueden ser explicadas por las condiciones no uniformes de mezcla vertical pero sí por los procesos locales termohalinos y la interacción de corrientes de densidad con la topografía de la cuenca.

\section{Conclusiones}

La estructura termohalina del cuerpo costero profundo de la Bahía de La Paz se forma bajo un equilibrio entre el comportamiento de los procesos atmosféricos y el intercambio de agua con regiones adyacentes de mar abierto. Durante la época de verano, bajo el impacto atmosférico local se desarrolla una estratificación fuerte desde la superficie con gradientes verticales de temperatura hasta $0.3^{\circ} \mathrm{C} / \mathrm{m}$ y un incremento de salinidad de hasta 0.4 , debido al balance negativo entre precipitación y evaporación. En otoño se forma una capa superficial de mezcla hasta los $50 \mathrm{~m}$ de profundidad causada por el forzamiento del viento que induce una intensa mezcla vertical. La no uniformidad del calentamiento y de la evaporación, en conjunción con la intrusión del agua de mar abierto a través de las bocas, forman la distribución de masa caracterizada por una zona menos densa en los primeros $60 \mathrm{~m}$ al centro de la bahía (línea 4). Esta no homogeneidad tridimensional de la estructura termohalina debe provocar las corrientes de gradiente de 
not stable cyclonic vortex is formed to the northwest. Within the bay there was a low-density nucleus centered at line 4 , which is a condition for the existence of an anticyclonic vortex. This structure, as well as the distribution of the surface mixed layer depth, cannot be explained by the nonuniform conditions of vertical mixing, but rather by the local thermohaline processes and the interaction of density currents with the topography of the basin.

\section{Conclusions}

The thermohaline structure of the deep waterbody of Bahía de La Paz is formed under the equilibrium between the influence of the atmospheric processes and the water exchange with adjacent regions of the open ocean. During summer, due to the local atmospheric impact, a strong stratification is developed from the surface taht has strong vertical temperature gradients, up to $0.3^{\circ} \mathrm{C} / \mathrm{m}$, and increased salinity, up to 0.4 , because of the negative balance between precipitation and evaporation. In autumn, a surface mixed layer is formed down to $50-\mathrm{m}$ depth, caused by the intense vertical mixing forced by the wind. The nonuniformity of heating and evaporation, and the intrusion of water from the open ocean through the mouths, form the mass distribution characterized by a less dense zone in the first $60 \mathrm{~m}$, in the center of the bay (line 4). This nonuniformity of the three-dimensional thermohaline structure must create the density-gradient currents which, in the actual topography of the basin, compensate the slopes of the isopycnics with a slope greater than $0.5 \mathrm{~m} / \mathrm{km}$. This suggests the existence of a stable anticyclonic vorticity of thermohaline origin in the center of the bay.

In the zone with depths greater than $150 \mathrm{~m}$ there are no significant temporal variations of the thermohaline variables related to those of the surface layer. The deep body has its inertia and is formed under the influence open ocean waters, but it does not have the T-S characteristics of the Gulf of California Water. This is a local transformation effect, caused by deep mixing in winter and also by the influence of Subsurface Subtropical Waters that enter the Gulf of California through the mouth and have lower salinity than the Gulf of California Water.

The global effect of the El Niño 1997-98 is one of the major factors responsible for the $2.5^{\circ} \mathrm{C}$ increase in the temperature of the superficial mixed layer during the sampling of October 1997 in the Bahía de La Paz. For the November of 1998 sampling the same argument cannot be used since the winter was approaching and El Niño had already concluded.

\section{Acknoledgements}

This work was supported through both the project $3915 \mathrm{P}$ T9607 of the Mexican National Science and Technology Council (CONACyT) and the project 968017 of the Mexican Instituto Politécnico Nacional (CGEPI-IPN). We thank Dr. Ellis Glazier who edited the English-language text, and Dr. densidad, las cuales con la topografía real de la cuenca compensan las inclinaciones de las isopicnas con pendiente mayor de $0.5 \mathrm{~m} / \mathrm{km}$. Esto sugiere que al centro de la bahía se localiza una vorticidad anticiclónica estable de origen termohalino.

En la zona con profundidades mayores a $150 \mathrm{~m}$ no se registraron variaciones temporales significativas de los parámetros termohalinos, en relación con los de la capa superficial. El cuerpo de agua profundo tiene su inercia, y es formado bajo la influencia de aguas del mar abierto, pero no tiene las características T-S del Agua del Golfo de California. Éste es un efecto local de transformación causado por la mezcla profunda en el invierno, y también por la influencia de Aguas Subsuperficiales Subtropicales que entran al Golfo de California a través de su boca y tienen menor salinidad que las del Golfo de California.

El efecto global de El Niño de 1997-98 (Asanuma et al., 1999) es uno de los principales responsables del aumento promedio de temperatura de $2.5^{\circ} \mathrm{C}$ en la capa superficial de mezcla durante el muestreo de octubre de 1997 en la Bahía de la Paz. Para el muestreo de noviembre de 1998 no se puede argumentar lo mismo dado que el invierno estaba ya próximo y El Niño ya había concluido.

\section{Agradecimientos}

Esta investigación fue apoyada por el Consejo Nacional de Ciencia y Tecnología (CONACyT) y por la Coordinación General de Estudios de Postgrado e Investigación (CGEPI) del Instituto Politécnico Nacional (IPN), a través de los proyectos de investigación 3915P-T9607 y 968017, respectivamente. Agradecemos al Dr. Ellis Glazier por la edición del manuscrito en inglés, al Dr. Armando Trasviña (CICESE) por compartir los datos de la zona del Bajo de Espíritu Santo, al Ing. Alberto León Manilla y al Cap. Manuel Saldívar Reyes por su colaboración en la experimentación de campo.

Traducido al español por los autores.

Armando Trasviña for providing us with the data on the Espíritu Santo Shoal. We also thank Alberto León-Manilla and Manuel Saldívar-Reyes for ther technical collaboration during field studies.

\section{References}

Álvarez-Borrego, L.G. y Schwartzlose R. A. (1979). Masas de agua del Golfo de California. Ciencias Marinas, 6(1-2): 43-63.

Álvarez-Sánchez, L.G., Wyatt, B. y Stivenson, M.R. (1978). Corrientes en la región de la boca del Golfo de California en la primavera de 1970. Ciencias Marinas, 5(1): 105-118.

Asanuma, H., Rago, T.A., Collins, C., Chávez, F. and Castro, C. (1999). Hydrography of Central California Waters during the 1997-8 El Niño. Tech. Rep. NPS-OC-99-01. Naval Postrgraduate School, Monterey, California, $121 \mathrm{pp}$.

Atkinson, L.P. and Blanton, J.O. (1986). Processes that affected stratification in shelf water. In: C.N.K. Mooers (ed.), Baroclinic 
Processes on Continental Shelves. Coastal and Estuarine Sciences, AGU Publ., pp. 117-130.

Badan-Dangon, A., Koblinsky, C.J. and Baumgartner, T. (1985). Spring and summer in the Gulf of California. Observations of surface thermal pattern. Oceanologica Acta, 8(1): 13-22.

Blanco-Betancourt, J.R. (1996). Masas de agua y circulación en la capa superior en la entrada del Golfo de California, durante Octubre-Noviembre de 1994. Tesis de Maestría, UABC, Ensenada, México, 140 pp.

Castro, R., Mascarenhas, A.S., Durazo, R. y Collins, C.A. (2000). Variación estacional de la temperatura y salinidad en la entrada del Golfo de California, México. Ciencias Marinas,26(4): 561-583.

Collins, C.A., Garfield, N. Mascarenhas, A.S., Spearman, M.G. and Rago T.A. (1997). Ocean currents across the entrance to the Golf of California. J. Geophys. Res., 102(9): 20927-20936.

Cruz-Orozco R., Martínez-Noriega, C. y Mendoza-Maravillas, A. (1996). Batimetría y sedimentos de la Bahía de La Paz, B.C.S., México. Oceanides, 11(1): 21-27.

Dressler, R. (1982). Investigaciones sobre la constituyente $M_{2}$ de marea y circulación forzada por el viento en la Ensenada de La Paz, Baja California, mediante un modelo hidrodinámico numérico (HN). Sammlung von Publikationen Dressler, 17 pp.

Jiménez, A., Obeso, M., Alatorre, M.A., Troyo, S. y García, H. (1994). Hidrología de la Bahía de La Paz. Oceanología, 1(2): 115-131.

Lavín, M.F. y Badan-Bangon, A. (1997). Estructura Hidrográfica y Circulación del Golfo de California: Escalas estacional e Interanual. In: M.F. Lavin et al. (eds.), Contribuciones a la Oceanografía Física en México. Monografía No. 3, México City: Unión Geofísica Mexicana, pp. 141-171.
Obeso, N.M., Jiménez A.R.I. y Diéguez, S.T. (1993). Modelación de la Marea en La Bahía de La Paz, B.C.S. Investigaciones Marinas de CICIMAR, 8(1): 15-21.

Roden, G.I. (1958). Oceanographic and meteorological aspects of the Gulf of California. Pacific Science, 12: 21-45.

Roden, G.I. (1972). Thermohaline structure and baroclinic flow across the Gulf of California entrance and in the Revillagigedo Island region. J. Phys. Ocean., 2: 177-183.

Salinas-González, F., Zaytsev, O.V. and Troyo-Diéguez, S. (1997). Corrientes, Mareas y sus Espectros en la Playa Norte de la Barrera Arenosa el Mogote, La Paz B.C.S., México. Oceanides, 12(2): 6577.

Stern, M.E. (1977). Ocean Circulation Physics. Academic Press, 246 pp.

Torres-Orozco, E. (1993). Análisis volumétrico de las masas de agua del Golfo de California. Tesis de Maestría, CICESE, Ensenada, México, $80 \mathrm{pp}$.

Villaseñor, C.A. (1979). Distribución vertical de temperatura, salinidad y oxigeno disuelto en la Bahía de La Paz, B.C.S., durante la primavera de 1976. CalCOFI Reps., 20, 146-149.

Wyrtki, K. (1967). Circulation and Water Masses in the Eastern Ecuatorial Pacific Ocean. J. Ocean. Limnol., 1(2): 117-147.

Zaytsev, O.V., Salinas-González, F. and Troyo-Diéguez, S. (1998). Water Dynamics and Mixing Studies in the Coastal Zone of the Gulf of California. In: Proceedings of the Canadian Hydrographic Conference-1998: 267-276. 